\title{
PEMANFAATAN LIMBAH KULIT SINGKONG TERMODIFIKASI ALKANOLAMIDA SEBAGAI BAHAN PENGISI DALAM PRODUK LATEKS KARET ALAM: PENGARUH WAKTU VULKANISASI
}

\section{UTILIZATION OF CASSAVA PEEL WASTE MODIFIED ALKANOLAMIDE AS FILLER IN NATURAL RUBBER LATEX PRODUCTS: THE EFFECT OF DRYING TIME}

\author{
Hamidah Harahap*, Kelvin Hadinatan, Adrian Hartanto, Elmer Surya, Indra Surya \\ Departemen Teknik Kimia, Universitas Sumatera Utara, Jalan Almamater Kampus USU \\ Medan 20155, Sumatera Utara, Indonesia \\ *Penulis korespondensi. Tel.: +62-6182-12090; Fax.: +62-6182-13250 \\ E-mail: hamidah_usu@yahoo.com
}

Diterima: 23 Januari 2015 Direvisi: 24 Februari 2015 Disetujui: 2 Maret 2015

\begin{abstract}
The purpose of this research was to study the effect of drying time on the mechanical properties of natural rubber latex filled with cassava peel waste modified alkanolamide. Cassava peel is a waste, containing cellulose which is potential as fillers in natural rubber latex products. Cassava peel waste was dried and milled until the size of 100 mesh. Alkanolamide is one type of non-ionic surfactant which is synthesized from RBDPS (Refined Bleached Deodorized Palm Stearin) and diethanolamine. Alkanolamide has polar group which can modified cassava peel waste and make strong chemical bonding with natural rubber latex. The production of natural rubber latex products was started from pre-vulcanization at $70^{\circ} \mathrm{C}$ until the system was cured and the chloroform number has reached number 3. Natural rubber latex was formed into films by coagulant dipping and drying method at $120^{\circ} \mathrm{C}$ for 10 minutes and 20 minutes. Results show that longer drying time will improve the crosslink density and tensile strength of natural rubber latex products until the addition of $15 \mathrm{phr}$ cassava peel waste powder.
\end{abstract}

Keywords: drying time, alkanolamide, cassava peel, natural rubber latex.

\begin{abstract}
ABSTRAK
Penelitian ini bertujuan untuk mempelajari pengaruh waktu vulkanisasi terhadap sifat mekanik produk lateks karet alam berpengisi kulit singkong termodifikasi alkanolamida. Kulit singkong merupakan limbah yang mengandung selulosa dan berpotensi untuk digunakan sebagai bahan pengisi dalam produk lateks karet alam. Kulit singkong dikeringkan dan dihaluskan hingga berukuran 100 mesh. Alkanolamida merupakan surfaktan nonionik yang disintesis dari bahan baku RBDPS (Refined Bleached Deodorized Palm Stearin) dan dietanolamina. Alkanolamida mengandung gugus polar yang dapat memodifikasi tepung kulit singkong dan membentuk ikatan kimia yang kuat dengan lateks karet alam. Proses pembuatan produk lateks karet alam dimulai dengan proses pravulkanisasi pada suhu $70^{\circ} \mathrm{C}$ hingga lateks karet alam telah matang dan bilangan kloroform telah mencapai angka 3 . Lateks karet alam dicetak dengan menggunakan teknik pencelupan berkoagulan dengan metode pengeringan pada suhu $120^{\circ} \mathrm{C}$ selama 10 menit dan 20 menit. Hasil penelitian menunjukkan waktu vulkanisasi yang lebih lama dapat meningkatkan nilai densitas sambung silang dan kekuatan tarik produk lateks karet alam hingga penambahan 15 phr tepung kulit singkong.
\end{abstract}

Kata kunci: waktu vulkanisasi, alkanolamida, kulit singkong, lateks karet alam.

\section{PENDAHULUAN}

Lateks karet alam merupakan hasil penyadapan pohon Hevea brasiliensis. Lateks karet alam segar mengandung $30-40 \%$ partikel hidrokarbon karet yang terdiri dari cis 1,4 poliisoprena dan 2-3\% protein (Jayanthy \& Sankaranarayanan, 
2005). Lateks karet alam umumnya mempunyai sifat mekanik yang baik, namun lateks karet alam juga memiliki beberapa kelemahan sehingga tidak sesuai dengan produk yang diinginkan (Visakh et al., 2012). Untuk meningkatkan sifat mekanik tersebut, lateks karet alam diproses dengan beberapa jenis pengisi, seperti silika, tanah liat (clays), karbon hitam (carbon black) dan karbon nanotube (carbon nanotubes) (Hossain et al., 2013).

Singkong atau ubi kayu (Manihot utilissima Pohl) merupakan salah satu sumber karbohidrat lokal Indonesia yang menduduki urutan ketiga terbesar setelah padi dan jagung (Nurlaili et al., 2013). Menurut Badan Pusat Statistik (BPS), produksi singkong di Indonesia cenderung meningkat setiap tahunnya. Kulit singkong merupakan limbah hasil pengupasan pengolahan produk pangan berbahan dasar umbi singkong. Kulit singkong terkandung dalam setiap umbi singkong dan keberadaannya mencapai $16 \%$ dari berat umbi singkong tersebut (Hidayat, 2009). Melihat potensi dari limbah kulit singkong yang mengandung selulosa yang cukup tinggi, maka kulit singkong cocok digunakan sebagai pengisi organik dalam produk lateks karet alam. Hal ini disebabkan karena selulosa memiliki ikatan hidrogen yang kuat dan tidak mudah larut dalam pelarut (solvent) yang umum (Lindman et al., 2010).

Hal yang perlu diperhatikan untuk meningkatkan sifat mekanik produk lateks karet alam adalah keserasian antara matriks lateks karet alam dengan pengisi. Oleh karena itu, diperlukan penambahan bahan penyerasi seperti alkanolamida. Alkanolamida merupakan salah satu jenis surfaktan non-ionik yang memiliki gugus polar yang dapat memodifikasi pengisi tepung kulit singkong dan membentuk ikatan kimia yang kuat dengan lateks karet alam. Alkanolamida telah digunakan sebagai bahan penyerasi dalam produk lateks karet alam berpengisi kaolin sehingga produk lateks karet alam yang dihasilkan memiliki sifat mekanik yang lebih baik dibandingkan tanpa adanya modifikasi (Harahap et al., 2013).

Salah satu proses pembuatan produk lateks karet alam yang paling penting adalah proses vulkanisasi. Proses vulkanisasi merupakan proses terjadinya reaksi sambung silang (crosslinking) antara molekul cis 1,4 poliisoprena akibat adanya agen vulkanisasi seperti sulfur (belerang). Akibat reaksi vulkanisasi, sulfur akan membuat ikatan sambung silang antara molekul-molekul cis 1,4 poliisoprena satu sama lain (Leroy et al., 2013).
Untuk itu perlu dilakukan tinjauan pengaruh lamanya waktu vulkanisasi terhadap sifat mekanik produk lateks karet alam yang dihasilkan.

\section{BAHAN DAN METODE}

\section{Bahan Penelitian}

Lateks karet alam dengan kandungan karet kering 60\% diperoleh dari pasar lokal di Medan, Sumatera Utara. RBDPS (Refined Bleached Deodorized Palm Stearin) diperoleh dari PT. Socfin Indonesia di Medan, Sumatera Utara. Kulit singkong diperoleh dari industri keripik singkong rumah tangga di Medan, Sumatera Utara. Kulit singkong dibersihkan, dikeringkan, dan dihaluskan hingga berukuran 100 mesh. Bahan-bahan kimia seperti kalium hidroksida $(\mathrm{KOH})$, natrium hidroksida $(\mathrm{NaOH})$, asam asetat $\left(\mathrm{CH}_{3} \mathrm{COOH}\right)$, kalsium nitrat tetrahidrat $\left(\mathrm{Ca}\left(\mathrm{NO}_{3}\right)_{2} \cdot 4 \mathrm{H}_{2} \mathrm{O}\right)$, toluena $\left(\mathrm{C}_{6} \mathrm{H}_{5} \mathrm{CH}_{3}\right)$, kloroform $\left(\mathrm{CHCl}_{3}\right)$, dietanolamina $\left(\left(\mathrm{C}_{2} \mathrm{H}_{4} \mathrm{OH}\right)_{2} \mathrm{NH}\right)$, natrium klorida $(\mathrm{NaCl})$, dietil eter $\left(\left(\mathrm{C}_{2} \mathrm{H}_{5}\right)_{2} \mathrm{O}\right)$, metanol $\left(\mathrm{CH}_{3} \mathrm{OH}\right)$, natrium metoksida $\left(\mathrm{CH}_{3} \mathrm{ONa}\right)$, dan natrium sulfat $\left(\mathrm{Na}_{2} \mathrm{SO}_{4}\right)$ dengan merek MERCK diperoleh dari CV. Multi Kreasi Bersama, Medan, Indonesia. Bahan-bahan kuratif seperti agen vulkanisasi sulfur, aktivator zink oksida $(\mathrm{ZnO})$, agen pencepat reaksi zink dietildithiocarbamate (ZDEC), dan antioksidan (AO) diperoleh dari Farten Technique (M) Sdn Bhd, Pulau Penang, Malaysia.

\section{Peralatan Penelitian}

Peralatan penelitian terdiri dari oven merek Memmert BE 200, hot plate merek Cimarec, ceramic ball mill diameter $15 \mathrm{~cm}$, pengaduk magnetik, neraca analitik merek Ohaus, rotary evaporator, ayakan 100 mesh dengan standar internasional ASTM E11, penangas air, refluks kondensor, labu leher tiga, gelas ukur, beaker glass, corong gelas, vessel flask, kertas saring merek Whatman, dan pelat seng. Peralatan uji meliputi uji sifat mekanik Universal Testing Machine (UTM) Gotech Al-7000 M, uji morofologi Scanning Electron Microscopy (SEM) JEOL-JSM-6510 LV, dan uji Fourier Transform Infra Red (FTIR) Shimadzu IR-Prestige 21.

\section{Metode Penelitian \\ Pembuatan bahan penyerasi alkanolamida}

Alkanolamida disintesis dari bahan baku RBDPS dan dietanolamina. Sebanyak 50 gram RBDPS dan 25,6 gram dietanolamina dimasukkan ke dalam labu leher tiga. Lalu ditambahkan 5 


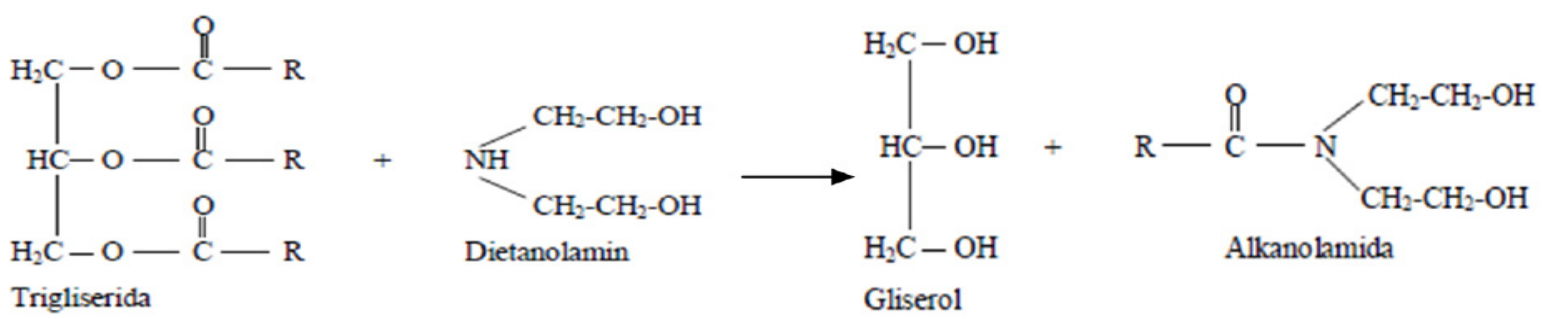

Gambar 1. Reaksi amidasi trigliserida dengan dietanolamina membentuk alkanolamida (Surya et al., 2013).

gram katalis natrium metoksida (dilarutkan dalam $20 \mathrm{ml}$ metanol). Campuran dipanaskan dan diaduk pada suhu $60-70^{\circ} \mathrm{C}$ selama 5 jam. Hasil reaksi diuapkan dengan alat rotary evaporator dan residu dilarutkan dalam $100 \mathrm{ml}$ dietil eter. Kemudian ditambahkan larutan $\mathrm{NaCl}$ jenuh hingga terbentuk dua lapisan. Diambil lapisan atas dan ditambahkan natrium sulfat anhidrat selama 45 menit lalu disaring dengan menggunakan kertas saring. Filtrat yang diperoleh diuapkan dengan alat rotary evaporator hingga pelarutnya habis. Residu yang diperoleh dianalisis dengan analisa FTIR. Mekanisme reaksi pembuatan alkanolamida dapat dilihat pada Gambar 1.

\section{Pravulkanisasi dan vulkanisasi lateks karet alam}

Tepung kulit singkong dan alkanolamida terlebih dahulu didispersikan di dalam ball mill dengan kadar tepung kulit singkong sebanyak $10 \%$, alkanolamida sebanyak $1 \%$ dan sisanya adalah air. Larutan dispersi tepung kulit singkong dan alkanolamida tersebut diambil sebanyak 0,5 , 10, 15, 20, dan $25 \mathrm{phr}$ dan dicampurkan ke dalam lateks karet alam beserta bahan-bahan kuratif. Tabel 1 menunjukkan formulasi lateks karet alam dengan bahan kuratif dan larutan dispersi tepung kulit singkong dan alkanolamida.

Proses pravulkanisasi dilakukan pada suhu $70^{\circ} \mathrm{C}$ hingga lateks karet alam telah matang dan angka kloroform telah menunjukkan angka 3. Kemudian campuran didiamkan selama 24 jam. Lateks karet alam pravulkanisasi dicetak dengan menggunakan teknik pencelupan berkoagulan. Pelat seng terlebih dahulu dibersihkan dengan larutan asam asetat $10 \%$, kalium hidroksida $10 \%$, aquadest, dan kalsium nitrat $10 \%$. Pelat seng yang telah bersih lalu dikeringkan dalam oven pada suhu $100^{\circ} \mathrm{C}$ selama 5 menit. Pelat seng didinginkan sebentar dan dicelupkan dalam lateks karet alam pravulkanisasi. Pelat seng dengan lateks karet alam pravulkanisasi dikeringkan dalam oven pada suhu $120^{\circ} \mathrm{C}$ selama 10 menit dan 20 menit. Produk lateks karet alam dipisahkan dari pelat seng dengan ditaburkan bubuk kalsium karbonat.

Produk lateks karet alam mengalami pengujian seperti uji densitas sambung silang (crosslink density) dengan standar internasional ASTM D471 (Da Costa et al., 2001). Uji densitas sambung silang (crosslink density) dihitung dengan menggunakan persamaan Flory-Rehner seperti persamaan (1) berikut ini :

$$
\left(2 \mathrm{M}_{\mathrm{C}}^{-1}\right)=\frac{\left[-\ln \left(1-\mathrm{V}_{\mathrm{r}}\right)-\mathrm{V}_{\mathrm{r}}-\chi \cdot \mathrm{V}_{\mathrm{r}}^{2}\right]}{2 \cdot \rho_{\mathrm{NRL}} \cdot \mathrm{V}_{0}\left(\mathrm{~V}_{\mathrm{r}}^{1 / 3}\right)}
$$

$\left(2 \mathrm{M}_{\mathrm{C}}{ }^{-1}\right)$ adalah densitas sambung silang, $\mathrm{V}_{0}$ adalah volume molar, $\chi$ adalah parameter interaksi dari pelarut (untuk toluene, $\mathrm{V}_{0}=108,5 \mathrm{~mol} . \mathrm{cm}^{-3}$ dan $\chi$ $=0,39), \rho_{\mathrm{NRL}}$ adalah densitas karet $=0,932 \mathrm{~g} \cdot \mathrm{cm}^{-3}$, $\mathrm{V}_{\mathrm{r}}$ adalah fraksi volume karet dalam gel yang membengkak, dihitung dari persamaan (2) berikut ini :

$\mathrm{V}_{\mathrm{r}}=\frac{\mathrm{W}_{\mathrm{d}} / \rho_{\mathrm{d}}}{\mathrm{W}_{\mathrm{d}} / \rho_{\mathrm{d}}+\mathrm{W}_{\text {sol }} / \rho_{\mathrm{sol}}}$

Tabel 1. Formulasi lateks karet alam dengan bahan kuratif dan dispersi tepung kulit singkong dan alkanolamida.

\begin{tabular}{lc}
\hline \multicolumn{1}{c}{ Bahan } & Kadar (phr) \\
\hline $\begin{array}{l}\text { High ammonia lateks } 60 \% \\
\text { karet kering }\end{array}$ & 100 \\
Larutan sulfur 50\% & 1,8 \\
Larutan ZDEC 50 \% & 1,8 \\
Larutan ZnO 30\% & 0,5 \\
Larutan antioksidan 50 \% & 1,2 \\
Larutan KOH 10 \% & 1,8 \\
Dispersi tepung kulit sing- & $0 ; 5 ; 10 ; 15 ;$ \\
kong dan alkanolamida & $20 ; 25$ \\
\hline
\end{tabular}


$\mathrm{W}_{\mathrm{d}}$ adalah massa awal karet, $\rho_{\mathrm{d}}$ adalah densitas karet (untuk karet vulkanisasi, $\rho_{\mathrm{d}}=0,9203 \mathrm{~g} . \mathrm{cm}^{-3}$ ), $\mathrm{W}_{\text {sol }}$ adalah massa pelarut yang terserap dalam karet, dan $\rho_{\text {sol }}$ adalah densitas pelarut (untuk toluene, $\rho_{\text {sol }}=0,87 \mathrm{~g} \cdot \mathrm{cm}^{-3}$ ).

Uji sifat-sifat mekanik seperti uji kekuatan tarik (tensile strength), perpanjangan putus (elongation at break), dan modulus tarik (tensile modulus) dengan standar internasional ASTM D412. Morfologi patahan produk lateks karet alam dianalisis dengan SEM di Laboratorium SEM, Fakultas Matematika dan Ilmu Pengetahuan Alam, Institut Teknologi Bandung. Produk lateks karet alam juga dikarakterisasi dengan FTIR di Laboratorium Penelitian, Fakultas Farmasi, Universitas Sumatera Utara.

\section{HASIL DAN PEMBAHASAN}

\section{Densitas Sambung Silang (Crosslink Density)}

Gambar 2 menunjukkan hubungan waktu vulkanisasi terhadap densitas sambung silang produk lateks karet alam berpengisi tepung kulit singkong termodifikasi alkanolamida. Waktu vulkanisasi yang lebih lama akan meningkatkan terjadinya reaksi sambung silang (crosslink reaction) dan meningkatkan pembentukan ikatan sambung silang (crosslink formation) (Vinod et al., 2002). Hal ini dibuktikan dengan nilai densitas sambung silang yang lebih tinggi untuk waktu vulkanisasi selama 20 menit dibandingkan dengan waktu vul-

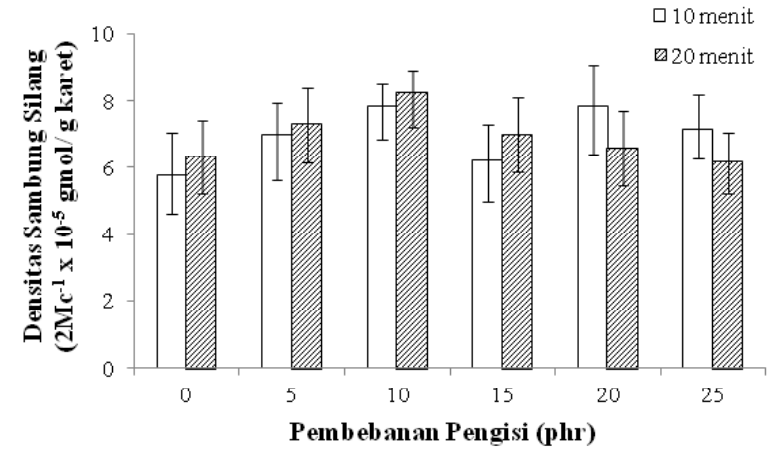

Gambar 2. Pengaruh waktu vulkanisasi pada densitas sambung silang (crosslink density) produk lateks karet alam berpengisi tepung kulit singkong termodifikasi alkanolamida.

kanisasi selama 10 menit. Gambar 3 menunjukkan reaksi sambung silang antara lateks karet alam dengan pengisi selulosa dan bahan kuratif.

Disamping itu, pembebanan pengisi lebih lanjut diatas 25 phr tepung kulit singkong menurunkan nilai densitas sambung silang produk lateks karet alam. Pembebanan pengisi yang lebih lanjut akan meningkatkan interaksi antara pengisi dengan pengisi itu sendiri (filler-filler bonding) dan mengurangi interaksi antara lateks karet alam dengan pengisi (filler-rubber bonding) (Azura et al., 2008). Interaksi antara lateks karet alam dengan pengisi sangat diperlukan untuk menghasilkan produk lateks karet alam yang baik.

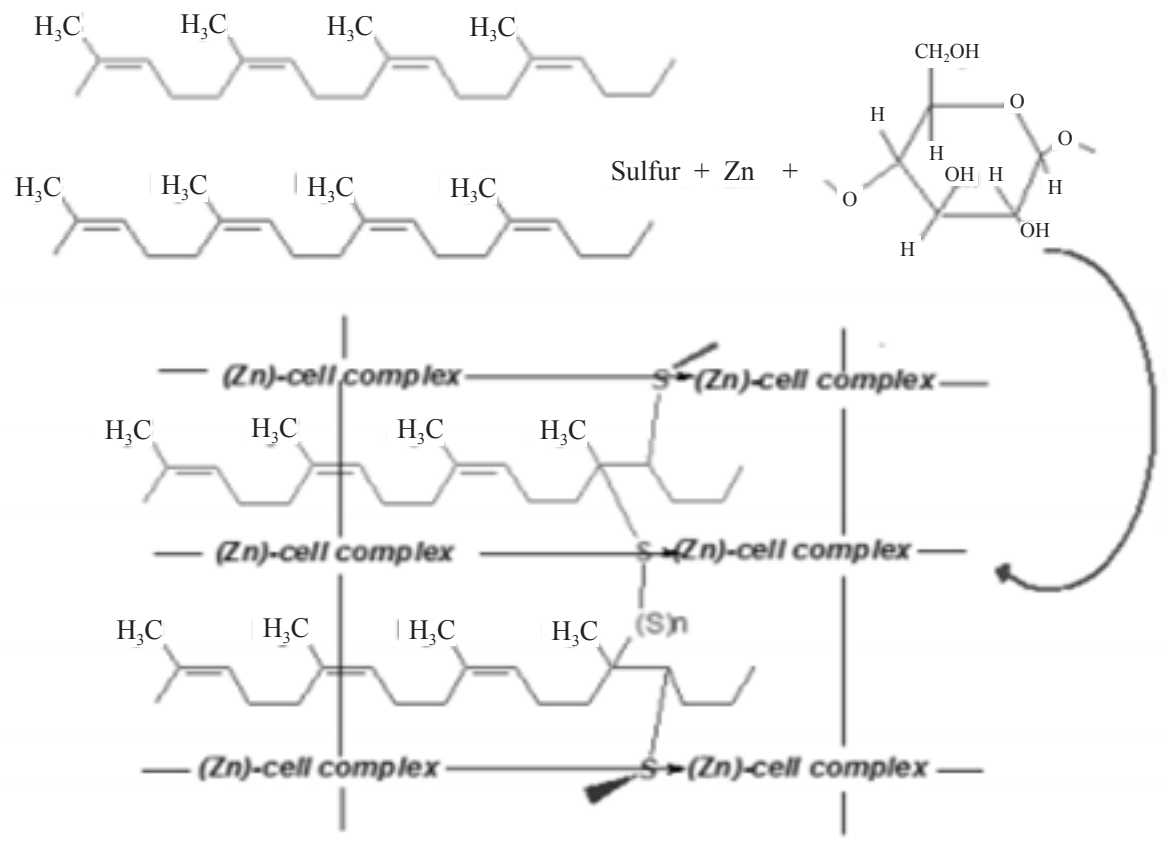

Gambar 3. Reaksi antara lateks karet alam dengan pengisi selulosa dan bahan kuratif (Abraham et al., 2013). 


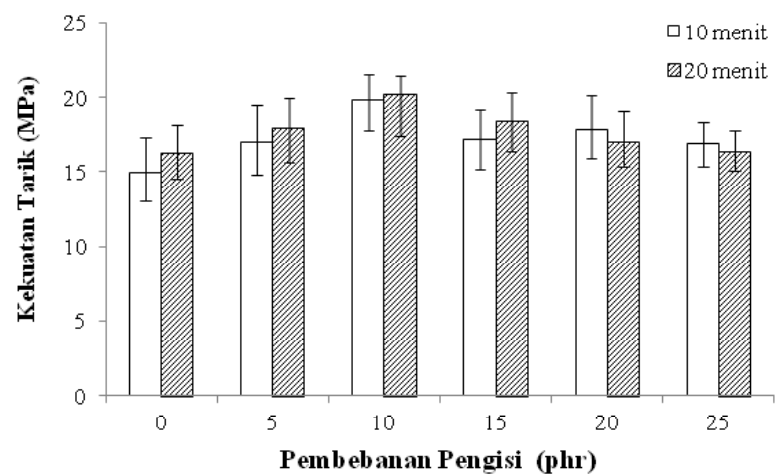

Gambar 4. Pengaruh waktu vulkanisasi pada kekuatan tarik (tensile strength) produk lateks karet alam berpengisi tepung kulit singkong termodifikasi alkanolamida.

\section{Kekuatan Tarik (Tensile Strength)}

Gambar 4 menunjukkan hubungan waktu vulkanisasi terhadap kekuatan tarik produk lateks karet alam berpengisi tepung kulit singkong termodifikasi alkanolamida. Nilai kekuatan tarik bergantung pada nilai densitas sambung silang. Kekuatan tarik akan mencapai nilai maksimum pada nilai densitas sambung silang yang paling besar. Hal ini disebabkan karena reaksi sambung silang akan menahan sebagian besar gaya yang diberikan pada produk lateks karet alam. Semakin banyak reaksi sambung silang yang terjadi, maka semakin banyak gaya yang diperlukan untuk memutuskan ikatan sambung silang dalam lateks karet alam (Ismail \& Chia, 1998). Hal ini dibuktikan dengan nilai kekuatan tarik optimum terdapat pada sampel dengan pembebanan pengisi $10 \mathrm{phr}$ tepung kulit singkong dengan waktu vulkanisasi selama 20 menit. Nilai kekuatan tarik juga menurun seiring dengan bertambahnya bahan pengisi yang ditunjukkan dengan menurunnya nilai densitas sambung silang.

\section{Perpanjangan Putus (Elongation at Break)}

Gambar 5 menunjukkan hubungan waktu vulkanisasi terhadap perpanjangan putus produk lateks karet alam berpengisi tepung kulit singkong termodifikasi alkanolamida. Seperti telah dijelaskan sebelumnya, waktu vulkanisasi yang lebih lama akan meningkatkan nilai densitas sambung silang. Semakin besar nilai densitas sambung silang maka produk lateks karet alam yang dihasilkan cenderung bersifat lebih rapuh sehingga sifatsifat elastisnya akan menurun (Ignatz-Hoover et al., 2003). Penambahan pengisi tepung kulit

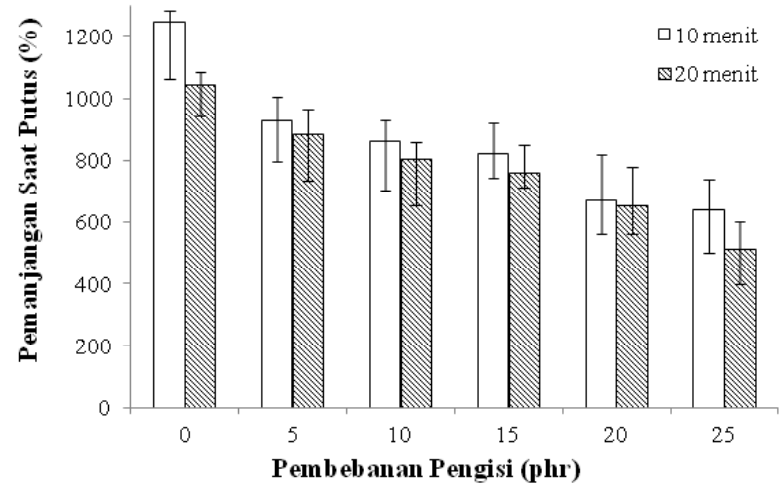

Gambar 5. Pengaruh waktu vulkanisasi pada pemanjangan saat putus (elongation at break) produk lateks karet alam berpengisi tepung kulit singkong termodifikasi alkanolamida.

singkong dalam produk lateks karet alam akan membuat nilai pemanjangan saat putus semakin menurun. Hal ini disebabkan karena kulit singkong mengandung selulosa yang dapat memberikan efek kekakuan (stiffening effect) pada produk lateks karet alam. Selulosa memiliki ikatan hidrogen yang kuat dan tidak mudah larut dalam pelarut (solvent) yang umum.

\section{Modulus Tarik (Tensile Modulus)}

Gambar 6 menunjukkan hubungan waktu vulkanisasi terhadap modulus tarik saat pemanjangan $100 \%$ dan $300 \%$ (M100 dan M300) produk lateks karet alam berpengisi tepung kulit singkong termodifikasi alkanolamida. Modulus tarik menunjukkan nilai keelastisan (elasticity) dari produk vulkanisat. Nilai modulus tarik yang kecil menunjukkan sifat bahan yang elastis sedangkan nilai modulus tarik yang besar menunjukkan sifat bahan yang kaku dan getas. Oleh karena itu, nilai modulus tarik memiliki hubungan berbanding ter-

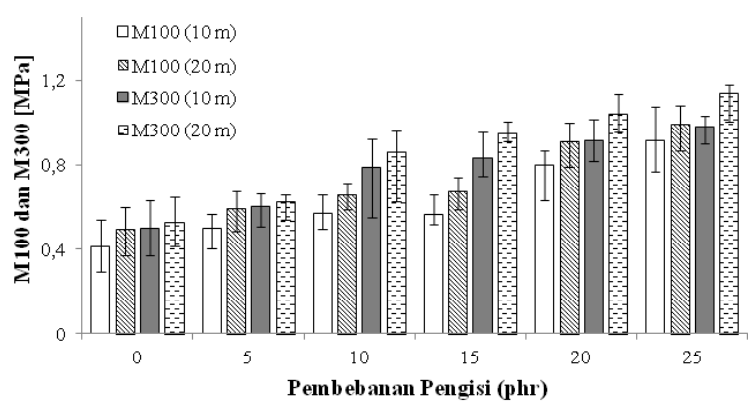

Gambar 6. Pengaruh waktu vulkanisasi pada modulus tarik (tensile modulus) produk lateks karet alam berpengisi tepung kulit singkong termodifikasi alkanolamida. 


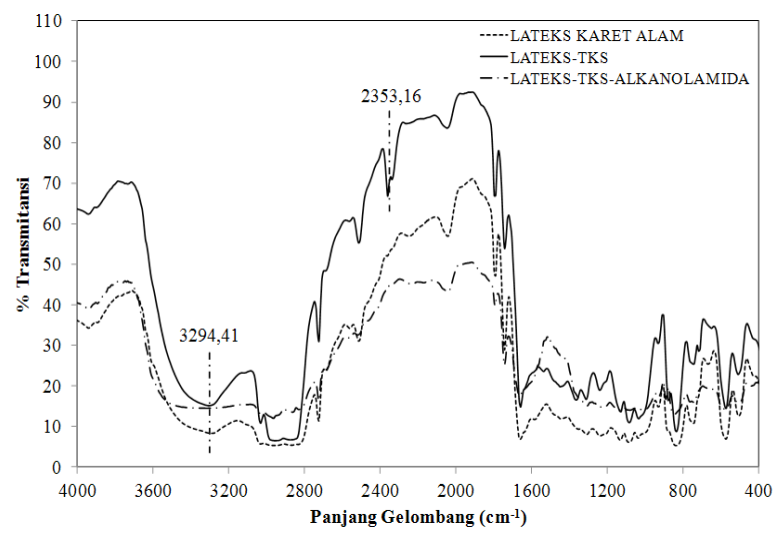

Gambar 7. Karakteristik FTIR produk lateks karet alam dengan dan tanpa penambahan pengisi tepung kulit singkong dan penyerasi alkanolamida.

balik dengan pemanjangan saat putus (elongation at break).

Karakteristik FTIR dari produk lateks karet alam dengan dan tanpa penambahan pengisi tepung kulit singkong dan penyerasi alkanolamida dapat dilihat pada Gambar 7.

Dari hasil analisis FTIR produk lateks karet alam menunjukkan bahwa terdapat perubahan pada gugus fungsi produk lateks karet alam dengan dan tanpa penambahan pengisi tepung kulit singkong dan penyerasi alkanolamida. Terdapat puncak serapan pada bilangan gelombang 2353,16 $\mathrm{cm}^{-1}$ pada produk lateks karet alam berpengisi tepung kulit singkong. Bilangan gelombang ini menunjukkan keberadaan gugus $\mathrm{O}-\mathrm{H}$ yang merupakan gugus fungsi utama selulosa kulit singkong. Hal

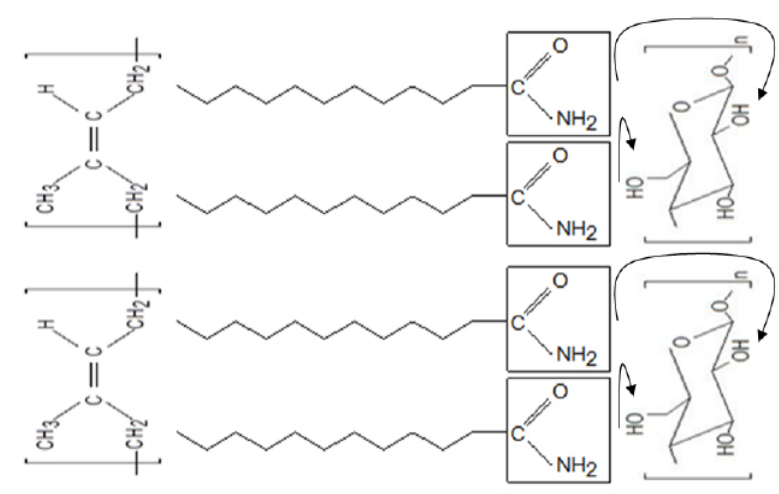

Lateks Karet Alam

Kulit Singkong
Gambar 8. Mekanisme reaksi antara lateks karet alam dengan pengisi tepung kulit singkong dan penyerasi alkanolamida.

ini menunjukkan bahwa pengisi kulit singkong telah terdispersi dalam produk lateks karet alam.

Penambahan alkanolamida dalam produk lateks karet alam menurunkan puncak serapan pada bilangan gelombang 2353,16 $\mathrm{cm}^{-1}$ yang menunjukkan keberadaan gugus $\mathrm{O}-\mathrm{H}$. Hal ini disebabkan karena gugus amida dalam senyawa alkanolamida yang bersifat sangat polar telah berikatan dengan gugus O-H pada kulit singkong sehingga menghasilkan eter. Di samping itu, penambahan alkanolamida dalam produk lateks karet alam juga menurunkan puncak serapan pada bilangan gelombang 3294,41 $\mathrm{cm}^{-1}$ yang menunjukkan keberadaan gugus $\mathrm{N}-\mathrm{H}$. Hal ini disebabkan karena senyawa alkanolamida telah menurunkan ikatan peptida $(\mathrm{N}-\mathrm{H})$ dalam protein
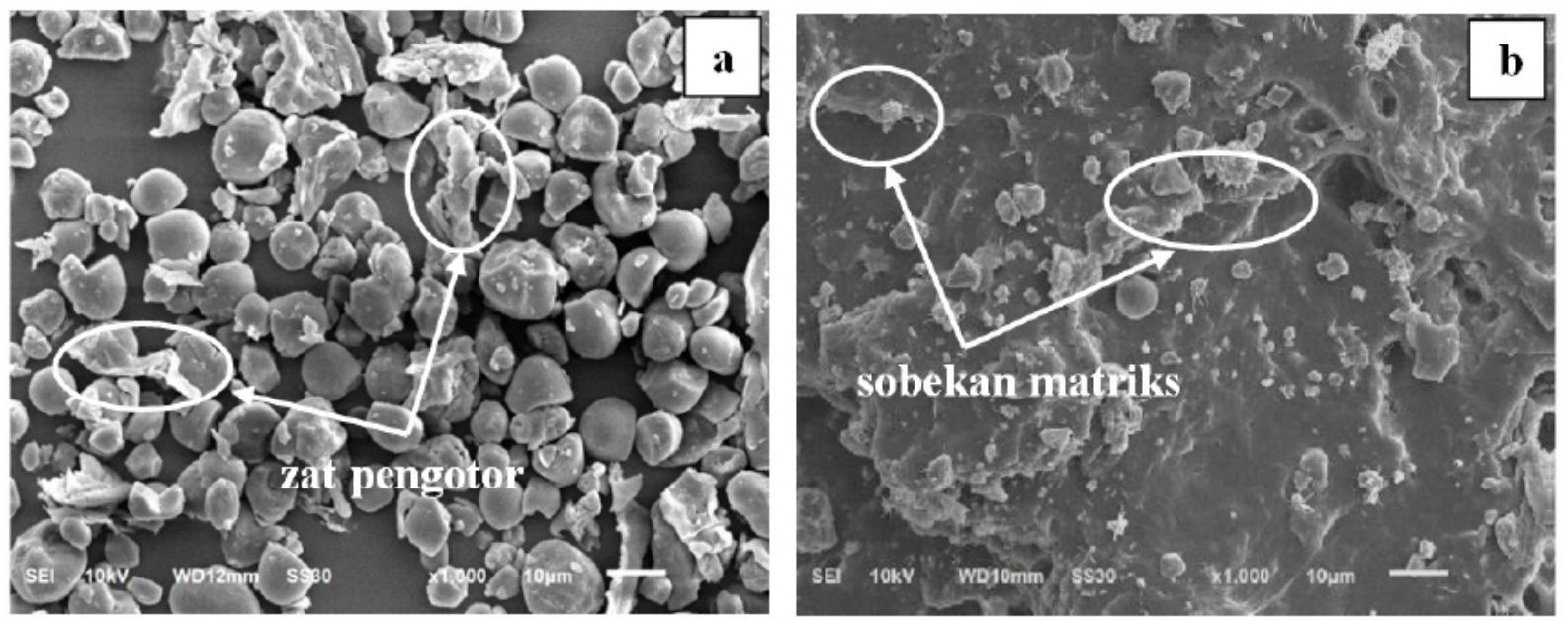

Gambar 9. Karakteristik SEM (a) tepung kulit singkong dan produk lateks karet alam berpengisi tepung kulit singkong termodifikasi alkanolamida pada pembebanan pengisi (b) $10 \mathrm{phr}$ dengan perbesaran 1000x. 
pada produk lateks karet alam.

Mekanisme reaksi antara lateks karet alam dengan pengisi tepung kulit singkong dan penyerasi alkanolamida ditunjukkan oleh Gambar 8.

Karakterisasi SEM (Scanning Electron Microscope) tepung kulit singkong dan produk lateks karet alam dapat dilihat pada Gambar 9. Gambar 9 (a) menunjukkan hasil karakterisasi SEM partikel pengisi tepung kulit singkong yang berukuran 100 mesh dengan perbesaran 1000x. Hasil karakterisasi SEM menunjukkan bahwa morfologi partikel tepung kulit singkong hampir memiliki ukuran yang seragam. Dapat dilihat bahwa tepung kulit singkong masih mengandung zat pengotor ( $\mathrm{impu}$ rites) yang disebabkan karena tepung kulit singkong masih memiliki kandungan lainnya seperti lignin, pentosan, dan abu.

Pada Gambar 9 (b) terlihat bahwa pengisi tepung kulit singkong telah terdistribusi secara merata dalam lateks karet alam dan memberikan permukaan yang halus. Hal ini disebabkan karena penambahan senyawa alkanolamida yang telah meningkatkan kekuatan antarfasa (interfacial adhesion) antara matriks lateks karet alam dan pengisi tepung kulit singkong. Di samping itu, penambahan alkanolamida juga memberikan efek sobekan matriks (matrix tearing) pada produk lateks karet alam. Sobekan matriks merupakan bentuk usaha produk lateks karet alam dalam menahan gaya yang diberikan saat pengujian kekuatan tarik (Ismail et al., 2012). Hal ini dibuktikan oleh nilai kekuatan tarik maksimum terdapat pada produk lateks karet alam dengan penambahan 1,0\% senyawa alkanolamida.

\section{KESIMPULAN}

Alkanolamida sebagai bahan penyerasi (compatibilizer) memiliki gugus polar yang mampu memodifikasi pengisi tepung kulit singkong dan gugus non polar yang mampu memodifikasi matriks lateks karet alam. Waktu vulkanisasi selama 20 menit dapat meningkatkan sifat mekanik produk lateks karet alam seperti densitas sambung silang dan kekuatan tarik dibandingkan dengan waktu vulkanisasi selama 10 menit. Penambahan pengisi tepung kulit singkong hingga $10 \mathrm{phr}$ dapat meningkatkan nilai densitas sambung silang sebesar $8,214 \times 10^{-5}$ gram.mol/gram karet dan nilai kekuatan tarik sebesar 20,115 MPa. Perpanjangan saat putus produk lateks karet alam menurun seiring dengan bertambahnya pengisi tepung kulit singkong. Hal ini disebabkan karena kulit singkong mengandung selulosa yang dapat memberikan efek kekakuan pada produk lateks karet alam.

\section{UCAPAN TERIMA KASIH}

Peneliti mengucapkan terima kasih kepada lembaga penelitian DIKTI yang telah menyumbangkan dana penelitian.

\section{DAFTAR PUSTAKA}

Abraham, E., Deepa, B., Pothan, L. A., John, M., Narine, S. S., Thomas, S., \& Anandjiwala, R. (2013). Physicomechanical properties of nanocomposites based on cellulose nanofibre and natural rubber latex. Cellulose, 20(1), 417-427.

Azura, A. R., Ghazali, S., \& Mariatti, M. (2008). Effects of the filler loading and aging time on the mechanical and electrical conductivity properties of carbon black filled natural rubber. Journal of Applied Polymer Science, 110(2), 747-752.

Da Costa, H. M., Nunes, R. C. R., Visconte, L. L. Y., \& Furtado, C. R. G. (2001). Physical properties and swelling of natural rubber compounds containing rice husk ash. Raw Materials and Applications, 54(5), 242-249.

Harahap, H., Surya, I., Kamil, E., Khoesoema, E., \& Surya, E. (2013). The effect of drying temperature on mechanical properties of the natural rubber latex products filled with kaolin modified alkanolamide. In Asean $^{++} 2013$ Moving Forward. Chiang Mai, Thailand: Chiang Mai University.

Hidayat, C. (2009). Peluang penggunaan kulit singkong sebagai pakan unggas. Seminar Nasional Teknologi Peternakan dan Veteriner, 655-657.

Hossain, K. M. Z., Sharif, N., Dafader, N. C., Haque, M. E., \& Chowdhury, A. M. (2013). Physicochemi$\mathrm{cal}$, thermomechanical, and swelling properties of radiation vulcanised natural rubber latex film: Effect of Diospyros peregrina fruit extracts. ISRN Polymer Science, 2013.

Ignatz-Hoover, F., To, B. H., Datta, R. N., De Hoog, A. J., Huntink, N. M., \& Talma, A. G. (2003). Chemical additives migration in rubber. Rubber Chemistry and Technology, 76(3), 747-768.

Ismail, H., \& Chia, H. H. (1998). The effects of multifunctional additive and epoxidation in silica filled natural rubber compounds. Polymer Testing, 17(3), 199-210.

Ismail, H., Muniandy, K., \& Othman, N. (2012). Fatigue life, morphological studies, and thermal aging of rattan powder-filled natural rubber composites as a function of filler loading and a silane coupling agent. BioResources, 7(1), 0841-0858.

Jayanthy, T., \& Sankaranarayanan, P. E. (2005). Measurement of dry rubber content in latex using microwave technique. Measurement Science Review, 5(3), 50-54. 
Leroy, E., Souid, A., \& Deterre, R. (2013). A continuous kinetic model of rubber vulcanization predicting induction and reversion. Polymer Testing, 32(3), 575-582.

Lindman, B., Karlström, G., \& Stigsson, L. (2010). On the mechanism of dissolution of cellulose. Journal of Molecular Liquids, 156(1), 76-81.

Nurlaili, F., Suparwi, \& Sutardi, T. R. (2013). Fermentasi kulit singkong (Manihot Utilissima Pohl) menggunakan Aspergillus niger pengaruhnya terhadap kecernaan bahan kering (KBK) dan kecernaan bahan organik (KBO) secara in vitro. Jurnal Ilmiah Peternakan, 3(1), 856-864.

Surya, I., Ismail, H., \& Azura, A. R. (2013). Alkanolamide as an accelerator, filler-dispersant and a plasticizer in silica-filled natural rubber compounds. Polymer Testing, 32(8), 1313-1321.
Vinod, V. S., Varghese, S., \& Kuriakose, B. (2002). Degradation behaviour of natural rubber-aluminium powder composites: effect of heat, ozone and high energy radiation. Polymer Degradation and Stability, 75(3), 405-412.

Visakh, P. M., Thomas, S., Oksman, K., \& Mathew, A. P. (2012). Crosslinked natural rubber nanocomposites reinforced with cellulose whiskers isolated from bamboo waste: Processing and mechanical/ thermal properties. Composites Part A: Applied Science and Manufacturing, 43(4), 735-741. 